Philosophy and Progress: Vols. LV-LVI, January-June, July-December, 2014 ISSN 1607-2278 (Print), DOI : http://dx.doi.org/10.3329/pp.v55i1-2.26389

\section{CLASSICAL LIBERALISM AND ITS LIMITS}

\author{
Golam Azam*
}

\begin{abstract}
It is widely considered that minorities' rights and dignity are protected in liberal societies particularly in western liberal countries up to a level humanly possible. However, in this article I show that it's not as much heroic a theory as we conceive specifically when the liberal society is committed to accommodate plurality of ideas and lifestyles. After briefly explaining principal tenets of classical liberalism I claim that some fundamental weakness of the theory makes it untenable in liberal plural society let alone non-western society of diversity.
\end{abstract}

\section{Introduction}

Western societies, it is often assumed, are capable of solving the problems associated with diversity because of the liberal tradition that they have inherited. In this article I focus on classical liberalism - the liberalism that comes from the writings of John Locke, John Stuart Mill and others and has been developed and refined by recent philosophers like John

\footnotetext{
* Associate Professor, Department of Philosophy, University of Dhaka, E-mail: golam4azam@du.ac.bd
}

Rawls, Ronald Dworkin, Brian Barry and many others. The views of these philosophers on key concepts of classical liberalism: liberty, equality, toleration and neutrality have been critically explored. The practice of these ideas, Galston (1988; 2002) calls these liberal virtues, enhances confidence among the individuals from majority or minority ethnic or religious groups regarding their rights and access to opportunity to public resources. In order to interpret the ideas with clarity I rely on the basic writings of the philosopher mentioned earlier as well as academic writings on contemporary political thinkers, for example, I. Berlin, Will Kymlicka, Janna Thompson, William Galston, Thomas Nagel, G A Cohen among others. They are liberal thinkers as well as critic of different analysis of liberal ideas. Their writings help to make cross analysis of a particular idea e.g. liberty.

The particular concern of the discussion of these ideas in this paper is to observe the liberal mechanism aspiring to uphold the rights and accommodation of people of diverse community in a liberal society. It is critically endeavoured to determine whether classical liberalism is capable of managing diversity and protecting the interests of people of minority groups. It is argued that the ability of liberalism to do these things is limited - even in the context where liberal virtues are in practice among the individuals. For this reason, I assume, application of classical liberalism is not likely to be a solution to problems of diversity and conflict faced in many non-Western countries where most liberal virtues are not in practice as propagated by many western scholars.

\section{Liberty}

A fundamental feature of classical liberalism is its support for individual liberty. Advocacy of liberty - originating from a struggle against oppressive powers - is always anti-absolutist 
and anti-theocratic. Liberty means freedom of religion, freedom of speech, assembly and so forth, but for most liberals it means more. Most liberals, traditional and contemporary, consider 'liberty' as the core of liberal ethical and political theory. Locke, one of the founders of classical liberalism, believed that individuals are naturally free, subject only to the law of nature. According to Locke,

To understand political power correctly and derive it from its proper source, we must consider what state all men are naturally in. In this state men are perfectly free to order their actions, and dispose of their possessions and themselves, in any way they like, without asking anyone's permissionsubject only to limits set by the law of nature (1689 [2008], p. 3).

The natural right to liberty is a right not to be interfered with: "[to be at] liberty is to be free from restraint and violence from others" (Locke, 1980 pargphs, 6 \& 57). It is a right to what contemporary liberals describe as 'negative freedom'. Though Locke thinks that restrictions can be placed on the actions of individuals to give them advantages of a political society, these restrictions are justified only so far as they are necessary to obtain these goods. A government should uphold the right of individuals to dispose of their possessions and persons as they think fit. And if a government does not do this, its members are justified in dissolving it and forming a new government.

J S Mill thinks that every individual should be free to act according to his desires in matters concerning his own life. A society and its members should respect his liberty. Mill allows that society can interfere with free action on some conditions. He says,

...the sole end for which mankind are warranted, individually or collectively, in interfering with the liberty of action of any of their number, is self-protection. That the only purpose for which power can be rightfully exercised over any member of a civilized community, against his will, is to prevent harm to others (Mill, 2010, p. 10).

Prevention of harm to others is the only justification for limiting liberty. How the harm principle should be interpreted is a subject of controversy. But it is clear that Mill meant to ensure that individuals would have a large scope for exercising choice and living according to their ideas of the good.

For Mill, Locke and many classical liberals, liberty is what Berlin describes as negative liberty:

I am normally said to be free to the degree to which no man or body of men interferes with my activity. Political liberty in this sense is simply the area within which a man can act unobstructed by others. If I am prevented by others from doing what I could otherwise do, I am to that degree unfree; and if this area is contracted by other men beyond a certain minimum, I can be described as being coerced, or, it may be, enslaved (I Berlin, 1969, p. 122).

Negative liberty is negative because it is defined by the absence of something (i.e. of obstacles, barriers, constraints or interference from others) that could impede one's action. The negative concept of freedom is most commonly assumed in liberal defences of constitutional liberties typical of liberaldemocratic societies, such as freedom of movement, freedom of religion, and freedom of speech, and in arguments against paternalist or moralistic state intervention. It is also often invoked in defences of the right to private property, although some have contested the claim that private property necessarily enhances negative liberty (Cohen, 1995, p. 65). ${ }^{1}$

\footnotetext{
${ }^{1}$ After Berlin (1969), the most widely cited and best developed analyses of the negative concept of liberty include Hayek (1960) and Day (1970). Others include Gibbs (1976), C. Taylor (1979) and Christman (Christman,
} 2005, 1991). 
In Berlin's words, the negative concept of liberty is generally used in attempting to answer the question "What is the area within which the subject - a person or group of persons - is or should be left to do or be what he is able to do or be, without interference by other persons? Whereas the positive concept of liberty is commonly applied in attempting to answer the question What, or who, is the source of control or interference that can determine someone to do, or be, this rather than that?" (1969, pp. 121-122).

Some liberals like Joseph Raz (1982) and Charles Taylor (1992) think that positive liberty is fundamental to liberalism. According to their view, an individual's autonomy is the measure of his freedom. To enjoy positive liberty a person has to be self-determining, i.e. he has to be able to rationally choose and pursue his own ends. Self-determination requires the presence in an individual of self-control, self-mastery and an ability to be self-realizing. Theorists of positive liberty are concerned with internal factors that affect the individual's ability to act autonomously. These can include factors that come from an inadequate education or social conditioning. A woman nurtured in a closed society, says Christman (1991) will be constrained to choose in a way that her tradition requires. Though she does what she wants she is unfree. Those who stress the importance of autonomy are likely to insist that a liberal society should act to prevent people being acted on by forces that limit their autonomy. According to Carter,

...one might say that a democratic society is a free society because it is a self-determined society, and that a member of that society is free to the extent that he or she participates in its democratic process. But there are also individualist applications of the concept of positive freedom. For example, it is sometimes said that a government should aim actively to create the conditions necessary for individuals to be self-sufficient or to achieve self-realization (Carter, 2012).

Those who favour positive liberty in this sense generally think that everyone should be provided with resources sufficient to enable them to be truly free. They favour a distributive account of justice and other measures to ensure that individuals can become self-realizing.

From the above discussion on liberty we can understand why classical liberalism is widely regarded as a basis for a multicultural society. Negative liberty ensures that individuals are able to choose and practice their religion and maintain their culture without interference from the state or from others (so long as they are not harming people). Positive liberty in the sense of autonomy or of having options ensures that they can make a choice that is truly good for them and that they will not be constrained in the pursuit of their ideals by lack of resources.

\section{Equality}

All liberals insist that from a moral point of view individuals are equal. Every human being should be treated with equal respect. In liberal societies this requirement serves as a basic and minimum standard of equality and in liberal moral philosophy as a basis of moral justification. Liberals generally assume that persons are alike in important relevant and specific respects - by having the same basic needs, for example. Rawls identifies primary goods as goods that all individuals will require whatever goals they choose to pursue. They are what ought to be distributed to all members of a society according to his second principle of justice. However liberals do not assume that individuals are alike in their tastes, situation or preferences or that they should be treated in the same way (Nagel, 1991, pp. 67-68). Equality in their view is compatible with diversity 
and inequalities in personal attributes as well as with different ideas of the good.

Moral equality, in the political philosophy of liberals, translates into political equality. Individuals are equal citizens enjoying equally the rights that citizenship entails. The liberty that the state is supposed to allow, encourage and protect belongs to each citizen equally. According to Marshall, citizenship ought to ensure that everyone is treated as a full and equal member of society. He contends that "all who possess the status of citizenship are equal in respect to the rights and duties with which the status is endowed" (Marshall, 2009 [1950], pp. 149150). Marshall divides citizenship rights into three categories: civil rights, political rights and social rights. Civil rights comprise the right to freedom of speech, thought and belief, the right to own property and to conclude valid contracts and the right to justice. Political rights are the rights to vote and to hold political office. Social rights are the rights to education, healthcare, unemployment insurance and an old age pension (Kymlicka \& Norman, 1994, p. 354). For Marshall, the total expression of citizenship requires a liberal democratic welfare state. In a liberal welfare state every member of society is guaranteed civil, political and social rights. This type of state also ensures that every member of society feels like a full member of society, able to participate in and enjoy the common life of society (Kymlicka \& Norman, 1994, p. 354).

However, liberals differ on what equality means. Some liberals, like Nozick and Locke are opposed to any attempt by a liberal state to equalize resources. For them equality means equal rights of liberty and property, including an equal natural right to self-ownership. Every individual has the same natural right to acquire property - so long as enough and as good is left over for others. However many liberals, like Marshall, believe that equality requires that individuals receive an equitable share of social resources.

For utilitarians, an equitable share is one that maximizes utility when the interests of all individuals are equally considered. In utilitarian calculations everyone counts as one and no one as more than one - though this does not preclude a distribution that gives some individuals more than others. But many liberals are unhappy about the inequalities that might exist as the result of a utilitarian distribution. According to Rawls, utilitarianism does not take seriously the distinction between persons, a distinctness that makes it impermissible to discount a harm to one for the sake of the general good (Rawls, 1971, p. 187). He does not suppose that goods can or should be distributed equally - to do so is likely to stand in the way of increasing the wellbeing of all. However, inequalities must be justified by reference to the good they do for everyone, especially people in disadvantaged groups. According to him, the principles of justice are to be conceived as those that free and rational persons concerned to further their own interests would agree should govern their forms of social life and institutions if they had to choose such principles from behind "a veil of ignorance" - that is, in ignorance of their own abilities, of their psychological propensities and conception of the good, and of their status and position in society and the level of development of the society of which they are to be members (Rawls, 1971, pp. 11-13). The position of these choosing parties is called "the original position". One might think that our ignorance would leave us quite unable to make a rational choice. But Rawls holds that we are to imagine ourselves as having unlimited knowledge of general truths about the world and also knowledge of the 'primary social goods' of human life, which he takes to be rights, opportunities, wealth and self-respect. Furthermore we are to assume that our motivations in the 
original position are those of people who are "rational and mutually disinterested" (Rawls, 1971, p. 12), by which he means that they act to promote their own self-interest without any interest in one another's interests. According to Rawls, they would arrive at two principles of justice: 1) Each person has an equal right to a fully adequate scheme of equal basic liberties which is compatible with a similar scheme of liberties for all; 2) Social and economic inequalities must be attached to offices and positions open to all under conditions of fair equality of opportunity; and they must be to the greatest benefit of the least advantaged members of society (Rawls, 1971, 1982).

Liberal egalitarianism combines an acknowledgment of difference with a commitment to social and economic equality. Two types of equality appear in Rawls's principles of justice: "equality in connection with the distribution of goods, some of which will almost certainly give higher status or prestige to those who are favoured, and equality as it applies to the respect which is owed to persons irrespective of their social position" (Song, 2007, p. 44). Rawls says that the first kind of equality is defined by the second principle of justice and the second kind of equality is defined by his first principle of justice and by natural duties of mutual respect. Mutual respect includes a respect for the ability of individuals to choose and pursue their own idea of the good - thus allowing for diversity. As far as the difference principle is concerned, equality is the default position and inequalities require justification.

Equality also plays a central role in Dworkin's theory of justice. For him equality of respect is the basic liberal requirement. Equality of respect means the right to be treated with equal concern. He insists that a government "must not distribute goods or opportunities unequally on the ground that some citizens are entitled to more because they are worthy of more concern. It must not constrain liberty on the ground that one citizen's conception of good life is nobler or superior to another's" (Dworkin, 1978, p. 273). Respect for the individual is also his reason for insisting that the rights of individuals override utilitarian decision-making: “...if someone has a right to something, then it is wrong for the government to deny it to him even though it would be in the general interest" (Dworkin, 1978 , p. 269) . He is not opposed to differences in treatment. Equality does not mean treating everyone the same, and he allows that legislatures may distribute benefits and burdens unevenly provided basic rights are not affected. Nor does he oppose making decisions for the sake of the general good. But equality requires that the external preferences of individuals their preferences concerning the interests, attitudes and situation of others - not be counted in utilitarian calculations. To do so, would be a violation of the equal consideration that each individual is entitled to.

Behind Dworkin's insistence on equal respect, and thus equal rights, for individuals is the importance he places on individual responsibility, the exercise of personal choice and the pursuit of self-determination, all of which give substance to the idea of justice as a distinct and major moral ideal (Campbell, 1988, p. 52). Central to his political philosophy is a defence of equal treatment for members of minority groups. For him, the justification of a theory of justice lies in how it treats minorities in a society. According to the requirement of equality of respect, people should not be limited in their speech or actions just because a majority regards their activities as distasteful, threatening or immoral. The democratic decisions of a majority ought not to violate the equal rights of members of minorities. A liberal democratic society cannot remove political rights from minorities without ceasing to be liberal. He emphasizes that "the argument in favour of anti-discrimination, that a 
minority has a right to equal respect and concern, is an argument of principle" (Dworkin, 1978, p. 82).

\section{Toleration}

Liberals support toleration. For contemporary liberals, the ideal of toleration is closely linked to other liberal values: to the commitment to state neutrality, to the promotion of individual freedom, equal concern for individuals and to the preservation of social unity and peace (Torbisco Casals, 2006, p. 92). The negative version of toleration ("live and let live") requires people to abstain from interfering with the worship, speech and ways of living of others. Toleration as a duty of noninterference is the flip side of negative liberty. The right to liberty gives others a duty of toleration. But toleration has also been justified in other ways. Locke argued that civil and ecclesiastical authorities ought to tolerate diversity of religious belief because genuine belief cannot be legislated. Individuals do not choose at will what they believe. But he also supported toleration because he believed that political power should not be used to regulate those activities and interests of individuals that are purely private and have no harmful effects on others (Locke, 1997). For Mill toleration of the ideals and choices of others follows from his defence of liberty as self-realization. According to Forst, "...liberal ethical argument says that one should be tolerant because ethical autonomy, i.e. the autonomy to choose, pursue and possibly to change a concept of good, is a necessary presupposition for the good life" (Forst, 2001, p. 201).

Many liberals defend toleration as necessary for liberty or autonomy. Dworkin defends it as a requirement of equality of respect. Toleration for them is derived from a more fundamental moral commitment and is thus not itself fundamental. However some contemporary liberals believe that toleration is a fundamental liberal virtue - the virtue that allows a liberal society to incorporate a diversity of minority groups including those whose members are not liberals.

Toleration can take a moral or political form. Moral toleration can be understood as follows: "X is tolerant of $Y$ doing $Q$ if 1) $\mathrm{X}$ holds $\mathrm{Q}$ as an incorrect way of acting; 2) $\mathrm{X}$ is in possession of a means to prevent $\mathrm{Y}$ from doing $\mathrm{Q}$; and 3) $\mathrm{X}$ does not prevent $\mathrm{Y}$ from doing $\mathrm{Q}$ because he recognizes $\mathrm{Y}$ 's right to do Q” (Holowka, 2009; Holówka \& Jacórzyński, 2009, p. 157). Moral toleration thus requires individuals to exercise restraint in their reactions to the attitudes and behaviour of others including to behaviours that they find repugnant or even immoral. We should not try to coerce people to change their behaviour or to punish them for their beliefs (though toleration does not necessarily mean that we cannot criticize others or express our disagreement in a civil way). While moral toleration is about relations between agents, political toleration is about restraint of political power. Political toleration requires at least that the state must tolerate the practice of religions other than the 'state religion'. But since Locke political toleration is assumed to require state neutrality on religious and other ideological issues. Political toleration in a liberal democracy goes along with respect for privacy, separation of church and state, and as well as a respect for the liberty and equality of individuals.

All liberals agree that toleration has its limits. Liberals are supposed to tolerate the actions of individuals as long as they do no harm to others. But the harm principle raises questions about what counts as harm. Can a liberal society tolerate militant anti-liberals or people who are themselves intolerant? Answering this question is commonly thought to lead to a paradox. If anti-liberals or intolerant people are not tolerated then they are not being given the rights of free and equal 
individuals. The state, in other words, cannot be regarded as liberal. If anti-liberals and intolerant people are tolerated, then intolerance is being permitted. Thus whatever it does, the society fails to live up to the commitments of liberalism.

Fiala (2004) thinks that one way of resolving this paradox is to recognize a distinction between first-order judgments and second-order moral commitments. First-order judgments include emotional reactions and other practical judgments that focus on particular attitudes and behaviours. Second-order moral commitments include more complicated judgments that aim beyond emotion and particularity toward rational universal principles. With regard to the paradox of toleration there is a conflict between a first-order reaction against something and a second-order commitment to the principle of respecting liberty and the virtues of modesty or self-control. The paradox is resolved by recognizing that this second-order commitment trumps the first-order reaction. Thus we might have good reasons (based upon our second-order commitments) to refrain from following through on the normal consequences of negative first-order judgments (Fiala, 2004). However, when there is a genuine conflict of second-order commitments, that is, when the tolerant commitment to individual liberty runs up against an intolerant rejection of the liberty of others, then there is no need to tolerate. In other words the paradox is resolved when we realize that toleration is not a commitment to relativism but, rather, that it is a commitment to the value of liberty and to the distinction between first-order judgments and second-order moral commitments.

The practice of toleration as a virtue enables minorities to be accommodated in a liberal society. The distinctive ethnic and religious practices of minority groups are permitted, not interfered with and even respected by majority group members when a liberal society practices toleration. Toleration is therefore important in a liberal plural society for ensuring peace and encouraging harmonious coexistence of ethnic and religious groups.

\section{Liberal Neutrality}

The concept of neutrality is connected to liberal requirements of liberty and equality and toleration. Neutrality can be defined as "... the obligation to refrain from intervening to promote particular life plans or conceptions of the good, while ensuring equal opportunities for all citizens to pursue their particular ends" (Torbisco Casals, 2006, p. 87). According to Kymlicka, "A distinct feature of contemporary theory is its emphasis on "...neutrality - the view that the state should not reward or penalize particular conceptions of the good life but, rather, should provide a neutral framework within which different and potentially conflicting conceptions of the good can be pursued" (Kymlicka, 1989a, p. 883). This means, he says, that the state must not justify its policies on the basis of the intrinsic superiority or inferiority of particular conceptions of the good life and it must not attempt to influence people's judgments of the value of these different conceptions.

In the history of liberalism, neutrality has meant, above all, neutrality in respect to religion. The state is not supposed to favour one religious group over another. Neutrality in respect to religion is a means of dealing with diversity of religious belief within a society and was thus a solution to the conflicts over religion gripping Europe during the 16th and 17th centuries. Neutrality in matters of religion goes along with the advocacy of a secular state - a state that protects the rights of individuals but does not favour any particular religion or interfere with the religious life of individuals. In a secular state religion is assumed to be a private matter. Individuals are entitled to worship as they please - that is their business. But 
they should not attempt to use political power to favour their religious way of life.

Dworkin regards neutrality as required by the basic value of equality. Equal respect means that the state cannot promote the way of life favoured by the majority or interfere with a person's pursuit of her good even if the majority regards it as pernicious, disgusting or unworthy. The requirement of neutrality, he thinks, is the main element that distinguishes liberalism from conservatism and different forms of socialism (1985, pp. 191-192).

John Rawls thinks that liberty of individuals to determine and live by their idea of the good rules out any attempt by a state to limit or interfere with systems of belief that are basic to the ways in which people live their lives. "The state is not to do anything intended to favour or promote any particular comprehensive doctrine rather than another, nor to give greater assistance to those who pursue it" (Rawls, 1988, p. 257). In Political Liberalism (1993) the prospect of a stable consensus on principles of justice depends on the creation of an overlapping consensus. In an overlapping consensus, citizens support the same basic principles for reasons internal to their own comprehensive doctrines. Each religious or cultural group has a reason for supporting the principles from its point of view. The principles themselves do not rely on any particular conception of the good. Rawls proposes this political conception of justice to ensure that people who hold a wide variety of conception of the good can accept it. A political conception of justice is a "module" that can fit into any number of worldviews. Citizens work out for themselves how the liberal "module" fits into their own worldview. Some citizens may see liberal principles of justice as derived directly from their deepest beliefs while others may accept a liberal conception as attractive in itself but mostly separate from their other concerns. Individuals can understand and support the overlapping consensus from within their own comprehensive doctrine, but in public discussion they are required to employ justifications that do not depend on any particular comprehensive doctrine. Public reason, in Rawls's view, should not favour the worldviews of any particular group of citizens. An overlapping consensus that can be supported by public reason is thus for Rawls not only a way of ensuring social stability in a diverse society. It is stability that does not depend on the exercise of power by those who are in the majority. Abiding by liberal basic laws is not a citizen's second-best compromise in the face of the power of others, but each citizen's best option given their own beliefs. As Rawls sees it, public reason and an overlapping consensus ensure neutrality of the liberal state in a diverse society.

Neutrality is one of the most important features of a liberal society for accommodating difference. Impartial treatment of religion and culture by the liberal state ensures that people in minority ethnic and religious groups get equal treatment, opportunities and rights. Neutrality is supposed to ensure that they are free to practice their own religion, engage in their own cultural activities and live according to their idea of the good without being disadvantaged by the laws and political practices of their society or forced to accommodate themselves to the cultural practices of a majority.

\section{Inadequacy of Classical Liberal Solution}

From the viewpoint of people belonging to minority cultures and religions, there are four serious problems with classical liberalism. The first is that it focuses on individuals, thus ignoring group identities and the values individuals obtain from them. The second is that liberalism's conception of toleration does not encourage an appreciation of cultural difference. The 
third is that it's ideal of equal citizenship undermines the ability of groups to determine themselves and to preserve what they value; and the fourth is that liberal neutrality is illusionary. There is no such thing as a neutral liberal state.

Liberty for liberals is about individual liberty. Mill's defence of liberty is a defence of the ability of individuals to decide for them how they want to live and to break with convention and group expectations if it suits them to do so. However, many members of cultural and religious groups are concerned not so much with individual freedom - in some cases this is not their concern at all - but with the ability of their group to maintain its traditions and determine its own affairs. The problem is not just that some groups have ideals that do not easily fit into a liberal context. Liberalism by its emphasis on individuals and their interests seems to be ignoring a dimension of value that is important to many people. Communitarians like Charles Taylor believe that this is so. Liberalism, he says, treats individuals as if they were social atoms with no essential connection to each other. It does not recognise the need of individuals for a cultural context and close ties with others in order to make sense of their options or to exercise their capacity for choice (Charles Taylor, 1989, pp. 195-212; 1992). Though he rejects communitarianism, Kymlicka admits that many liberals, including Rawls, play down the importance of membership in a cultural community as a context of choice (Kymlicka, 1989b, p. 206). But if this membership does indeed play an important role in human life - as Kymlicka believes - then liberalism, at least in its classical form, is inadequate.

Second, classical liberals generally conceive toleration in a negative way - as non-interference. Toleration, so understood, is compatible with failure to appreciate the points of view of others - and thus with distrust and moral repugnance. What a multicultural society seems to need is mutual respect based on an understanding and appreciation of different points of view. Toleration needs to exist in a positive form. Toleration can be identified and explained as both a moral and a political ideal. As a moral ideal in a diverse country it suggests that an individual is morally obliged to be tolerant of diverse beliefs and ways of life. Toleration as a political ideal requires willingness to peacefully resolve disagreements and to build institutions that recognize and accommodate diversity. According to Jones, we should think of political toleration not as toleration that a government extends to those it rules but as a political ideal that governments should uphold and promote (2007, p. 383). Contemporary discussions on minority rights in liberal societies that engage with the idea of toleration usually focus on the question of how much liberal society should tolerate cultural practices of minority groups. The concern is with the proper limits of toleration in circumstances where the practice of minority cultural norms conflict with respect for the autonomy of vulnerable individual members of minority groups, such as women and children [e.g. Kukathas (2003)]. Such discussions presuppose that toleration is a value but they rarely discuss it as a value in its own right, considering instead how toleration supports other liberal values. They therefore miss the opportunity to consider whether toleration is valuable intrinsically or only instrumentally and what difference, if any, this sort of judgment might make to their assessments of the limits of toleration. They do not explain the value of toleration outside of the context of a liberal society.

The third problem for classical liberalism is its insistence on equal citizenship: the belief that everyone should have the same rights and responsibilities and be subject to the same law. This idea of citizenship is in obvious conflict with the desires of many groups of indigenous people who have their own idea of sovereignty and conception of law. But it is also a problem 
for other ethnic and religious groups that want to have the power to make their own communal decisions according to their idea of what is important for their group. Common citizenship, according to these group members, is a threat to group autonomy and distinctness. Kymlicka explains this in this way, "They demand the group-specific forms of citizenship because they reject the very idea that there should be a single common national culture or because they think that the best way to include people in such a common culture is through differentiated citizenship rights" (Kymlicka, 2002, p. 330).

The fourth problem is that liberal neutrality is an unrealizable ideal. According to Galston, the liberal state cannot "be properly understood as 'neutral' in any of the senses in which that term is currently employed. Like every other political community, it embraces a view of the human good that favours certain ways of life and tilts against others" (William A. Galston, 1991, p. 3). Every liberal state has a way of doing things that is influenced by its history and the dominance in it of particular cultural groups or religions. It has an official language (or languages) that belongs to the dominant groups. Its ceremonies make reference to the dominant group's religious texts; its official holidays are often the religious holidays of that group. Its laws enshrine the ideas of particular cultures. Moreover, the laws it makes are bound to be nonneutral in their effects.

... neutrality is an impossible ideal, since policies enacted for reasons that do not purposely seek to advantage or disadvantage any conception of good will inevitably be nonneutral in their effects. Legislating with an awareness for non-neutral effects is therefore tantamount to legislating for non-neutral purposes, albeit not explicitly. Neutrality becomes little more than cruel facade which conceals that it itself is 'highly discriminatory(Choudhry, 2002, p. 54).

Neus argues that liberals have to acknowledge that law and politics in liberal countries have an intrinsic cultural dimension. Terms like "non-intervention" or "benign neglect" are misleading in that

\begin{abstract}
...(t)hey reinforce the illusion that, if only neutrality was strictly applied through a strategy of privatization of cultural conflict, cultural minorities would be able to survive at the state's margins. Surely, if this were the case, there would be no need for a theory of group rights, or for a model of multicultural citizenship. But, ... a general principle of noninterference by the state in the cultural realm is untenable in the modern world and can only lead, by omission, to privileging a status quo that, in most cases, only reinforces the privileges of the dominant group (Torbisco Casals, 2006, p. 124).
\end{abstract}

If neutrality means that no policy or practice should have differential effects on cultural or religious groups, then neutrality clearly is unrealizable. Many advocates of neutrality, including Rawls, are concerned with neutrality in respect to justification. However, even this kind of neutrality might prove to be impossible. Iris Marion Young thinks that the ideal of neutrality that we find in the work of Rawls and other political liberals fails to take account of the differences between people, by forcing them to reason in ways that ignore their felt emotion and experiences. She criticizes the solution Rawls offers to the problem of cultural or value pluralism in the idea of an overlapping consensus. She argues that "the idea of comprehensive doctrine on which this account of political agreement relies is too thin a concept to capture the social realities of a multicultural society, and is also too totalizing" (Young, 1995, p. 181). In her phrase, it reduces 'difference to 
unity'. She thinks that neutrality as an ideal fails to recognize that people have deeply different lives, experiences and social roles - so different that an overlapping consensus and a common participation in public reason are not always possible. We should not try to pretend that there can be one neutral standpoint that can reduce all these differences to unity and make all these people the same (Young, 2011, p. 116).

Classical liberal theory can also be criticized for not taking into account the historical reasons for distrust and enmity that often exist between cultural groups - particularly majority and minority cultural groups. If one group has persecuted another for generations, then recognizing some rights for minorities may not be sufficient to overcome disadvantage or bring about toleration between groups. Historical resentments can also prevent immigrant groups from integrating into mainstream society. Distrust between majority and minority because of historic reasons is not likely to be removed simply by recognizing cultural rights or proclaiming equal status or rights. Thompson argues that it is our responsibility to rectify the past wrong otherwise liberal efforts to do justice to the oppressed minorities would remain incomplete (Thompson, 2002). Spinner-Halev contends that some historical injustices no longer persist as an injustice but as an enduring harm. $\mathrm{He}$ argues that the past scars some groups, but not necessarily because group members live under unjust circumstances. Some groups want the cruel events in the past acknowledged, not because doing so will enable them to live better lives, but because they find the denial of these terrible events a continuing affront. He also contends that only by taking the history of an enduring injustice into account can the liberal state understand how to repair many existing injustices (Spinner-Halev, 2007, pp. 575-576).

\section{Conclusion}

The critical analysis of classical liberalism presented above shows that classical liberalism might not be the best theory for dealing with cultural and religious differences. The question arises whether liberalism can be revised so that it is compatible with the desire of group members to preserve their traditions and able to take into account the values associated with group membership. In this globalized world every country is more or less multicultural or multiethnic. Hence, in order to ensure peace and harmony in plural countries, I think, the practice and promotion of toleration is something fundamentally needed. Another point I wish to emphasize is that if we look at the history we see very clearly how vigorously and intentionally the minority groups were deviated of their rights and social and political justice. Mentionable that such injustices were not only done in present liberal society but such atrocities were also done in many non-liberal countries. I think, the past injustices done to the minority groups day after day could be rectified within the liberal framework. I would like to deduce another conclusion from the issues discussed in this paper. That liberalism i.e. the practice of liberal ideals might not be a solution to the problems of differences and conflict in nonliberal plural countries. It is fundamentally because, a) as it is not capable enough to secure the interest of the minorities in liberal countries, it would be over demanding to see that liberalism i.e. liberalising is a better solution in non-liberal countries, and b) most people in non-liberal countries do not practice liberal virtues, for example, Myanmar is assumed as a non-liberal country where most people are not liberal and people's liberal rights of autonomy and equality are determined by the authority. They don't have any tradition of individual autonomy or equality. Therefore, liberalism is less functional in these types of countries than liberal countries. However, due to 
the limitation of classical liberalism some liberal thinkers talk about another theory, 'Liberal Multiculturalism', to accommodate minorities' rights properly in liberal countries. But, this paper is not the right place to discuss on this theory rather this task can be left for others to see if multicultural liberalism is really possible. There are, in fact, liberal philosophers who think that it is: that classical liberal theory can be modified in response to the demands of minorities without losing its commitment to central liberal values.

\section{Bibliography}

Berlin, I. (1969). Two Concepts of Liberty. In I. Berlin (Ed.), Four Essays on Liberty. London: Oxford University Press.

Berlin, I. (1969). Two Concepts of Libety in Four Essays on Liberty (pp. 118-172). London: Oxford University Press.

Campbell, T. (1988). Justice: Issues in Political Theory: MacMillan Education, Basingstoke.

Carter, I. (2012). Positive and Negative Liberty. In E. N. Zalta (Ed.), The Stanford Encyclopedia of Philosophy. <http://plato.stanford. edu/archives/spr2012/entries/liberty-positive-negative/>.

Choudhry, S. (2002). National minorities and ethnic immigrants: Liberalism's political sociology. Journal of Political Philosophy, 10(1), 54-78.

Christman, J. (2005). Saving Positive Freedom. Political Theory, 33, $79-88$

Christman, J. ( 1991). Liberalism and Individual Positive Freedom. Ethics, 101, 343-359.

Cohen, G. A. (1995). Self-Ownership, Freedom and Equality. Cambridge: Cambridge University Press.

Day, J. P. (1970). On Liberty and the Real Will. Philosophy and Pluralism, 45, 177-192.
Dworkin, R. (1978). Taking Rights Seriously: Harvard University Press.

Dworkin, R. (1985). Liberalism: A Matter of Principle London: Harvard University Press.

Fiala, A. (2004). Toleration. In J. Fieser \& B. Dowden (Eds.), Internet Encyclopedia of Philosophy, http://www.iep.utm.edu/ tolerati/.

Forst, R. (2001). Tolerance as a Virtue of Justice. Philosophical Explorations, 4(3), 193-206. doi: 10.1080/10002001098538716

Galston, W. A. (1988). Liberal Virtues. The American Political Science Review, 1277-1290.

Galston, W. A. (1991). Liberal Purposes : Goods, Virtues, and Diversity in the Liberal State. Cambridge ; New York: Cambridge University Press.

Galston, W. A. (2002). Liberal Pluralism : the Implications of Value Pluralism for Political Theory and Practice. Cambridge: Cambridge University Press.

Gibbs, B. (1976). Freedom and Liberation. London: Chatto and Windus.

Golam, A. (2010) Social Hamony, Multiculturalism and Cultural Pluralism, Philosophy and Progress, 45-46(1), 67-86.

Golam, A. (2008) Rawls' Theory of Justice and the Distribution of Health Care Resources in Low Income Countries, Philosophy and Progress, 41-42(2), 151-168.

Hayek, F. A. v. (1960). The Constitution of Liberty. London: Routledge and Kegan Paul.

Holowka, J. (2009). Social and Political Liberalism. In K. Wojciechowski \& J. C. Joerden (Eds.), Ethical liberalism in contemporary societies (Vol. 12). Germany: Peter Lang.

Holówka, J., \& Jacórzyński, W. (2009). Authors and Editors. Ethical Liberalism in Contemporary Societies, 12, 157. 
Jones, P. (2007). Making Sense of Political Toleration. British Journal of Political Science, 37(03), 383-402. doi: doi:10.1017/ S000712340700021X

Kukathas, C. (2003). The Liberal Archipelago: A Theory of Diversity and Freedom: Oxford University Press Oxford.

Kymlicka, W. (1989a). Liberal Individualism and Liberal Neutrality. Ethics, 99(4), 883-905.

Kymlicka, W. (1989b). Liberalism, Community, and Culture. Oxford England: New York: Clarendon Press ; Oxford University Press.

Kymlicka, W. (2002). Contemporary Political Philosophy : An Introduction (2nd ed.). Oxford ; New York: Oxford University Press.

Kymlicka, W., \& Norman, W. (1994). Return of the Citizen: A survey of recent work on citizenship theory. Ethics, 104(2), 352381 .

Locke, J. (1689 [2008]). Second Treatise of Government. Online; http://www.earlymoderntexts.com/pdfs/locke1689a.pdf.

Locke, J. (1980). Second Treatise of Government (1st ed.). Indianapolis, Ind.: Hackett Pub. Co.

Locke, J. (1997). Letter Concerning Toleration. In S. M. Cahn (Ed.), Classics of Modern Political Theory: Machiavelli to Mill. UK: Oxford University Press.

Marshall, T. H. (2009 [1950]). Citizenship and Social Class. In J. Mazna \& M. Sauder (Eds.), Inequality and Society: Social Science Perspectives on Social Stratification (pp. 148-154). New York: W W Norton and Co.

Mill, J. S. (2010). On Liberty and Other Essays: Digireads. com Publishing.

Nagel, T. (1991). Equality and Partiality: Oxford University Press on Demand.
Rawls, J. (1971). A Theory of Justice. Cambridge, Mass.: Belknap Press of Harvard University Press.

Rawls, J. (1982). The Basic Liberties and their Priority. The Tanner Lectures on Human Values, 3, 3-87.

Rawls, J. (1988). The Priority of Right and Ideas of the Good. Philosophy \& Public Affairs, 17(4), 251-276.

Rawls, J. (1993). Political Liberalism. New York: Columbia University Press.

Raz, J. (1982). Liberalism, Autonomy, and the Politics of Neutral Concern. Midwest Studies in Philosophy, 7(1), 89-120.

Song, S. (2007). Justice, Gender, and the Politics of Multiculturalism: Cambridge University Press.

Spinner-Halev, J. (2007). From Historical to Enduring Injustice. Political Theory, 35(5), 574-597.

Taylor, C. (1979). What's Wrong with Negative Liberty. The idea of freedom, 175-193.

Taylor, C. (1989). Cross-purposes: the liberal-communitarian debate. Debates in Contemporary Political Philosophy, 195.

Taylor, C. (1992). The Politics of Recognition. In A. Gutmann (Ed.), Multiculturalism and the 'Politics of Recognition'. Princeton: Princeton University Press.

Thompson, J. (2002). Taking Responsibility for the Past: Reparation and Historical Injustice. Cambridge: Polity.

Torbisco Casals, N. (2006). Group Rights as Human Rights. Netherlands: Springer.

Young, I. M. (1995). Rawls's Political Liberalism*. Journal of Political Philosophy, 3(2), 181-190.

Young, I. M. (2011). Justice and the Politics of Difference (New in Paper): Princeton University Press. 
